\title{
6.6
}

\section{Northern Ireland: local government and politics}

Local authorities play key roles in the devolved government of Northern Ireland, as expressions of communities that were in the past highly polarised on religious and political lines. They are also the only other source of elected legitimacy to the Northern Ireland Assembly and Executive (which have not been functioning for over a year and a half at the time of writing). Local councils can act as checks and balances on the domestic concentration of power. James Pow explores how democratically local councils have operated in difficult conditions.

\section{What does democracy require of Northern Ireland's local governments?}

$\downarrow$ Local governments should engage the wide participation of local citizens in their governance via voting in regular elections, and an open interest group and local consultation process.

४ Local voting systems should accurately convert parties' vote shares into seats on councils, and should be open to new parties entering into competition.

$\downarrow$ As far as possible, consistent with the need for efficient scales of operation, local government areas and institutions should provide an effective expression of local and community identities that are important in civil society (and not just in administrative terms).

$\downarrow$ Local governments should be genuinely independent centres of decision-making, with their own sufficient financial revenues and policy autonomy to be able to make meaningful choices on behalf of their citizens.

$\downarrow$ Given the special history of Northern Ireland, deliberative policy-making has a particularly key role in building local political harmony and understanding of multiple viewpoints and interests.

Local governments are typically subject to some supervision on key aspects of their conduct and policies by a higher tier of government. However, they should enjoy a degree of constitutional protection (or 'entrenchment') for key roles, and an 
assurance that they cannot simply be abolished, bypassed or fully programmed by their supervisory tier of government.

- The principle of subsidiarity says that policy issues that can be effectively handled in decentralised ways should be allocated to the lowest tier of government, closest to citizens.

\section{Recent developments}

In 2014 local government areas and structures went through the biggest shake-up to its structure and organisation since the early 1970s. A major 2005 review initially recommended that 26 local government districts be radically streamlined into just seven 'super-councils'. After devolution was restored at Stormont in 2007, the power-sharing administration ultimately made a compromise to reduce the number of districts, but only to 11. Of these, six have predominantly unionist electorates, four have predominantly nationalist electorates, and one (Belfast City) is relatively balanced.

\section{Figure 1: How structural reforms changed local government district areas}

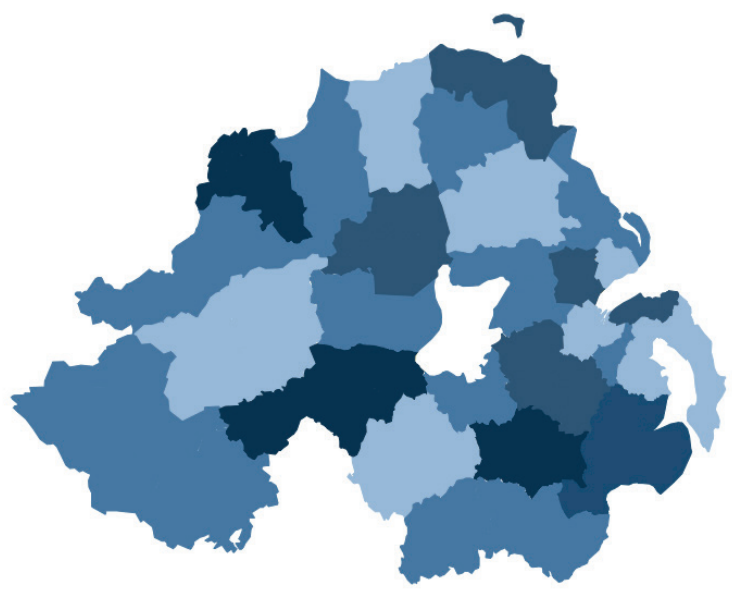

Pre 2014

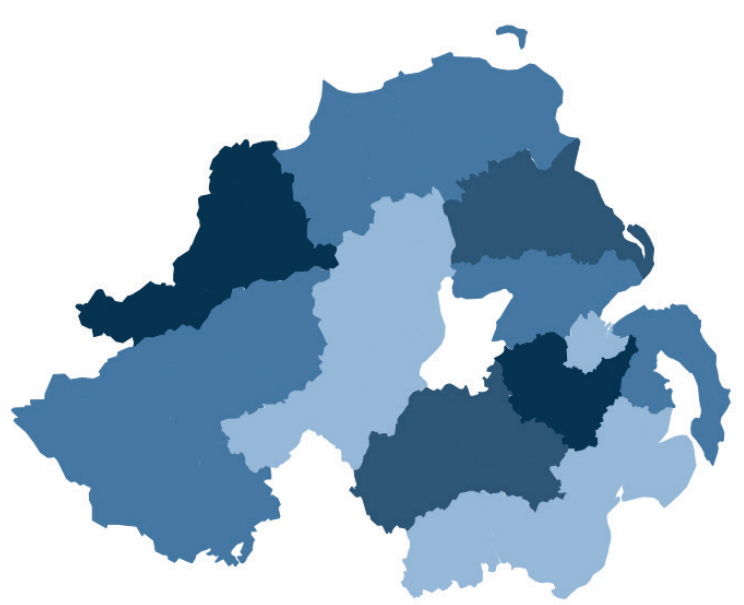

Since 2014

Source: James Pow

The first elections in the council districts took place in May 2014; the transfer of power from outgoing administrations was complete within a year. The reformed councils removed many 'legacy' features, and so provided fresh opportunities for citizens to re-engage with local government politics. A key hope for these reforms was also that councils themselves would improve the democratic quality of their decision-making processes. Their average size is over 171,000 people, far larger than their predecessors, with a range from 339,000 in Belfast City to 115,000 in rural Fermanagh and Omagh.

Northern Ireland councils have fewer responsibilities than councils elsewhere in the UK, partly because the province's relatively small population means some services can be delivered province-wide. In addition, the previously deeply divided nature of its society led 
to an emphasis on using non-sectarian quasi-governmental bodies rather than politicised councils to deliver services. The Housing Executive is Northern Ireland's single public housing authority, set up in 1971 in the wake of discriminatory housing allocations by district councils. It is technically an executive non-departmental public body (or NDPB), and operationally independent of the Northern Ireland Executive, but accountable to the Minister for Communities. Transport NI is the region's sole road authority. The Education Authority (EA) is responsible for all educational and library services. And the provision of social care is overseen by six trusts. These public bodies are each accountable to the Northern Ireland Executive, but not to local councils. While the Executive is not functioning they operate in a non-political way.

\section{Proportional elections in the new councils}

Apart from general elections for the Westminster Parliament, all elections in Northern Ireland are conducted using the single transferable vote electoral system (known as PRSTV in Northern Ireland). The council elections in 2014 using STV generated reasonably proportional results - that is, the number of first preferences received by each of the five main parties broadly corresponded to their total share of seats, to within a handful of percentage points. The results produced a deviation of proportionality (DV) score of $11.1 \%$. Historically this is much lower than the normal average scores for Britain's Westminster elections, using plurality rule voting (see Chapter 2.1). However, it is somewhat higher than the DV scores for Scottish local government using STV, or for the Northern Ireland Executive elections (see Chapter 2.3).

Figure 2: How the main parties' shares of votes compared to their share of seats in the 2014 council elections

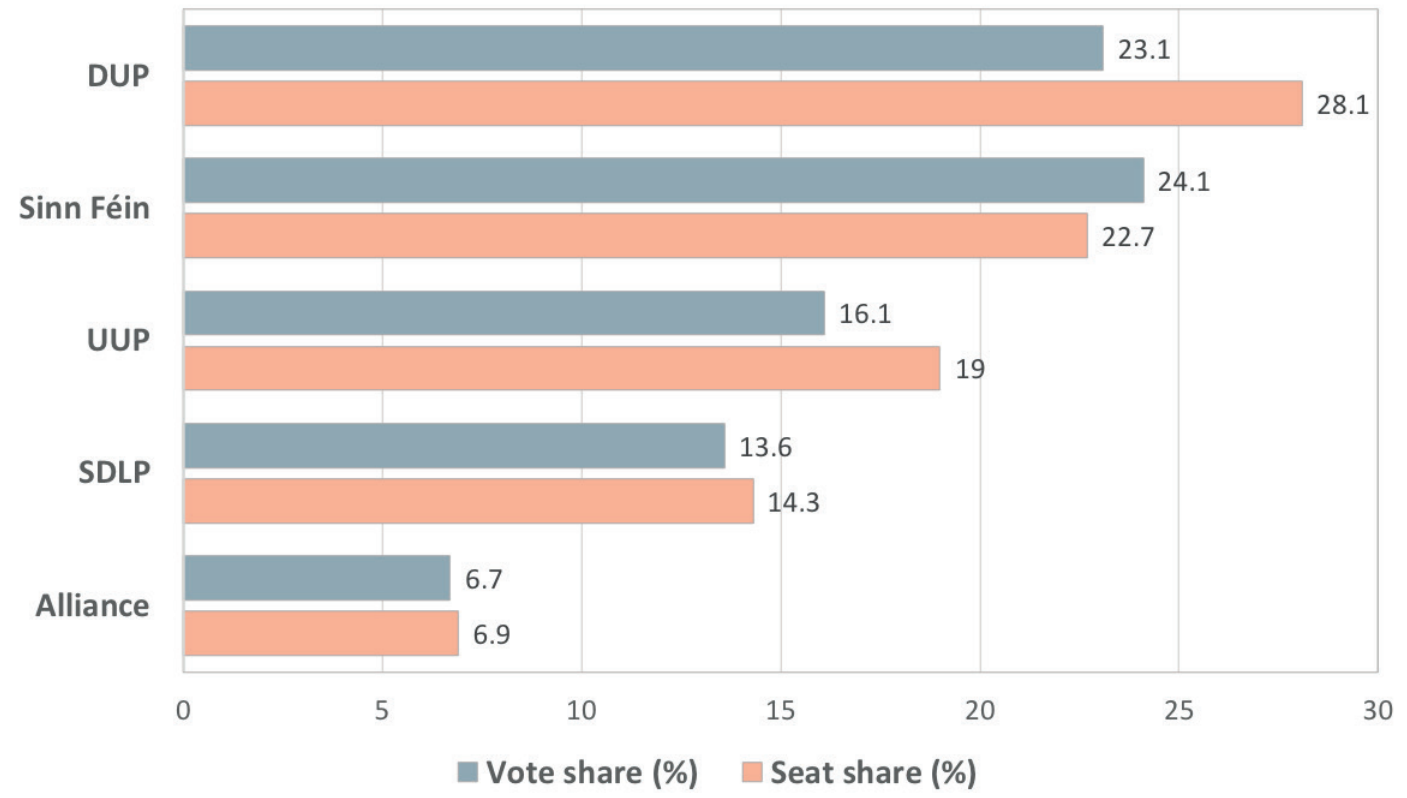

Notes: DUP: Democratic Unionist Party; SF: Sinn Féin; UUP: United Unionist Party; SDLP: Social Democratic and Labour Party. 
STV elections are preferential (so voters can number multiple choices of candidates 1, 2, 3 etc. in an order they choose) as well as proportional. So effective vote management and how voters transfer preferences to other parties can influence the results. In 2014, a fragmented distribution of first preference votes across smaller unionist parties divided their votes and harmed their chances of winning seats. Once these early preferences were eliminated in the counting process, then second or later preferences from these parties' voters were transferred to their next preferences. Figure 2 shows that the DUP gathered the most of these later vote transfers, thus apparently ending up 'over-represented' against their first preference votes. So voters who supported smaller parties are not necessarily left unrepresented - their first preference party may be knocked out, but they are represented by one lower down but still positive in their preferences.

Northern Ireland voters historically participate more in local government elections than those elsewhere across the UK. In 2014 the level fell back to just over 51\% of registered voters, a historic low for councils in the province, but still far more than to England's 36\% on the same day. The continued predominance of ethno-national voting in Northern Ireland (at all levels) encourages voters from rival political/religious groups to try and maximise unionist and nationalist representation respectively. Participation is also normally encouraged by holding council elections concurrently, that is on the same day as either Westminster or Assembly elections. However, in 2014 the only other elections held on that day were those for the European Parliament.

\section{Strengths, Weaknesses, Opportunities, Threats (SWOT) analysis}

\begin{tabular}{l|l|}
$\begin{array}{l}\text { Current strengths } \\
\begin{array}{l}\text { Local authorities across the UK have no } \\
\text { entrenched constitutional protections. } \\
\text { However, following their protracted } \\
\text { and controversial creation in 2014, and } \\
\text { especially during the prolonged inactivity } \\
\text { of the Executive and Assembly, the current }\end{array}\end{array}$ & $\begin{array}{l}\text { Current weaknesses } \\
\text { important groups are under-represented. } \\
\text { Only a quarter of councillors are women, less } \\
\text { than in the Assembly. Citizens who identify } \\
\text { as neither nationalist nor unionist may also } \\
\text { insulated from further changes in the } \\
\text { foreseeable future. }\end{array}$ \\
\hline $\begin{array}{l}\text { The STV electoral system is a proportional. } \\
\text { (PR) system, although in 2014 its was } \\
\text { less effective than normal for STV. The } \\
\text { preferential voting aspect of the system } \\
\text { minimises the likelihood of wasted votes. }\end{array}$ & $\begin{array}{l}\text { Relatively high levels of turnout may partly } \\
\text { reflect the continuing salience of sectarian } \\
\text { loyalties (linked to ethno-national political } \\
\text { competition) rather than a high level of } \\
\text { engagement with municipal issues per se. }\end{array}$ \\
\hline
\end{tabular}




\section{Current strengths}

Participation levels in local government elections are relatively high, facilitated by a tradition of holding them concurrently with elections to other levels of government.
Councillors are no longer permitted to hold multiple mandates. The shift away from 'double-jobbing' is designed to promote clearer electoral accountabilities.

\section{Current weaknesses}

Under STV you cannot easily hold byelections, since the process relies on multimember seats. Instead the political party holding the seat is allowed to nominate (co-opt in) a new person when councillor vacancies arise. This gives parties a lot of power, since one in ten councillors across Northern Ireland has been co-opted. Since the first sitting of the new councils in 2015, there have been 69 co-options across Northern Ireland, at least one in every district. The highest number was on Belfast City Council, where $28.3 \%$ of incumbent councillors were unelected as of August 2018.

Despite recent reforms of local government, there has been no effort to introduce innovative mechanisms of public consultation, such as citizen juries or planning cells.

The transfer of local planning powers to councils may help to promote transparency in and engagement with local decision-making.

\section{Future opportunities}

The transfer of some additional powers to local government level may increase support for additional democratic reforms, such as developing better or new forms of public consultation. Gaining these additional powers could help focus councillors' minds away from controversial issues of symbolism towards more substantive policy decisions that lack any obvious ethno-national connection.

\section{Future threats}

The elections for the Northern Ireland Assembly on 2 March, 2017 were preceded by a bitter campaign, showing an increasing salience of the ethno-national dimension. This may trigger regressive polarising motions and debates in local councils in reaction. As the dispute over the flying of the flag at Belfast City Hall demonstrated, decisions on sensitive issues - even if they are the result of a democratic procedure - can stir fervent opposition beyond the council chamber. 


\section{Future opportunities}

In the event that the fragile power-sharing administration fails to re-start (or collapses) at Stormont, representatives from the local government level will play a greater role in mitigating any democratic deficit.

\section{Future threats}

If direct rule has to be restored in some form, the oversight responsibilities for three key quasi-government agencies with urban roles - the Housing Executive, Education Authority and Transport $\mathrm{NI}$ - would likely transfer to Westminster, depending on the nature of the arrangement. This would add further distance between citizens and accountability mechanisms over major agencies of local/ regional government.

There is still not a consensus on all the key roles played by local governments across the main parties, and sensitive sectarian issues can arise in many applied policy contexts.

\section{Still 'tribal' elections?}

Just over half (52\%) of councillors elected in 2014 were elected to one of the main unionist parties, and $37 \%$ to one of the main nationalist parties. However, cross-sectional evidence from the annual Northern Ireland Life and Times Survey has consistently found since 2006 that at least $40 \%$ of citizens (a plurality) identify as neither nationalist nor unionist. As in higher levels of government, this group of voters appears to be systematically underrepresented under the existing party system.

The reformed structures of local government have not been accompanied by a significant improvement in women's representation. A quarter of councillors elected in 2014 were women, up just 1.6 percentage points on 2011. The aggregate level masks variation across the new districts. Women are a third of the members of Belfast City Council, but just onesixth of members on North Down and Ards Council.

Until new legislation prohibiting dual mandates came into effect in 2016, several incumbent members of the Northern Ireland Assembly (MLAs) were also elected to local government in 2014. The new rules now prevent the democratically dubious practice of 'double-jobbing'. However, the one-off councillor vacancies left by MLAs vacating their seats were filled by 'co-option' giving political parties, not voters, the exclusive right to nominate a successor.

\section{Some council planning powers, but not more transparency}

As part of the reorganisation of local government, the 11 new councils gained some additional powers from the Northern Ireland Executive. Most notably, decisions on the majority of planning applications and urban regeneration now rest at the level of local government, not the Department for Infrastructure. This transfer of power mandated by the 2011 Planning Act (Northern Ireland) has a democratic objective:

[The change] will make planning more locally accountable, giving local politicians the opportunity to shape the areas within which they are elected. 
Decision making processes will be improved by bringing an enhanced understanding of the needs and aspirations of local communities.'

A 2011 report on public and stakeholder opinion of the Northern Ireland planning system found it to be poorly regarded by citizens, developers and planners themselves. Citizens tended to see the relationship between planners and developers as too close, while developers tended to see the process as too inefficient. The reformed planning system remains in its infancy, so it is too early to tell whether or not the public and stakeholders perceive the revised system as more legitimate than its predecessor. At this stage, there is no evidence that the new councils have embraced global democratic innovations in planning, such as instigating citizen juries or deliberative planning cells. Regardless of their satisfaction with the new system, citizens and stakeholders may at least more clearly identify council representatives as accountable for decision-making.

\section{Budgets remain constrained}

As in Scotland and Wales, local councils receive most of their funding from the next tier up, here the Northern Ireland Executive. However, most of this money in turn comes from the UK Exchequer under the Barnett formula, which maintains a broad parity with England public spending. As a result of UK-level austerity policies, funding for Northern Ireland local authorities has declined appreciably.

\section{Symbolically important decisions can be contested}

Given councils' carefully limited powers of local government, it may be somewhat surprising that their decisions still spark intense controversy and raise fundamental questions over democratic legitimacy. But symbolism is still important. In December 2012 Belfast City Council voted to restrict the number of days that the Union Flag could be flown from City Hall. Nationalist councillors initially proposed a motion that would discontinue the flying of the flag altogether, but lacked a majority to carry it. The cross-community Alliance Party successfully proposed an amendment that would see the flag flying on 18 designated days during the year, in line with official government guidelines. In the end 29 councillors supported the amendment, but all 21 unionist councillors voted against.

The decision prompted street protests across Northern Ireland, some of which turned violent. Loyalists saw the decision as an attack on their British identity. A public consultation conducted as part of an Equality Impact Assessment suggested that a large number of citizens would be offended by any change to the council's policy. The Chief Constable of the Police Service of Northern Ireland blamed loyalist paramilitaries for orchestrating disorder. The Alliance Party, holding the balance of power on Belfast City Council, was a key target. Some of its councillors' homes were attacked, one of its offices was set alight and destroyed, and its sole MP (Naomi Long) received a death threat. Violence eventually dissipated, but the council's decision stood. Small, peaceful protests have been held outside Belfast City Hall every Saturday afternoon ever since.

This case study shows how a democratic decision, made after a major public consultation, can still face widespread disorder in a politically polarised society like Northern Ireland. 
Even if a decision is made following consultation and in line with majority views, the decision itself may lack sufficient buy-in on a cross-community basis. Each of the 11 new reorganised councils has made individual decisions on flag-flying policies. Some decisions have attracted protests, but none of the intensity or scale of those seen in Belfast in 2012.

\section{Northern Ireland politics in flux}

At the time of writing, Northern Ireland has been without a devolved power-sharing government for over a year and a half. After a snap Assembly election on 2 March, 2017 and a highly acrimonious campaign, the two largest parties, the Democratic Unionist Party (DUP) and Sinn Féin, failed to reach agreement for many months on the formation of a new administration (see Chapter 6.5). Meanwhile, civil servants have been left to manage government departments without ministerial direction or oversight, with the UK government reluctant to introduce direct rule from Westminster. If the UK government does eventually assume responsibility for matters devolved under the Northern Ireland Act (1998), it will diminish potential oversight over public services from Northern Irelands' voters, especially on housing, education and road maintenance (see above), with particular alienation likely to be felt from Irish nationalists. Connections with local council services may suffer too, since the vast majority of Westminster MPs lack experience in, or any strong incentive to understand, local governance in Northern Ireland.

The June 2017 general election brought the DUP into supporting the Conservative's minority government at Westminster. This complicated matters by potentially jeopardising the UK government's ability to be seen as impartial arbiters in Northern Ireland politics.

\section{Conclusions}

Local government in Northern Ireland apparently meets many democratic criteria to an encouraging extent, especially in the electoral legitimacy of councillors, high turnouts at elections, and a continuing ability to engage citizens' political interest. However, the continued predominance of the ethno-national dimension at all levels of Northern Ireland politics casts doubt on the extent to which citizens engage with the substantive issues of local government, impairs the deliberative and consensual quality of their decision processes, and has caused democratically controlled local powers to be kept very minimal. Still, at the time of writing, councillors have been the only elected officials making public policy decisions in Northern Ireland for over a year and a half. Despite their comparatively narrow remit, local governments have maintained some reality behind devolved powers across the region.

James Pow is a postgraduate research student at the School of History, Anthropology, Philosophy and Politics, Queen's University Belfast. 